DISTRIBUTION SHEET

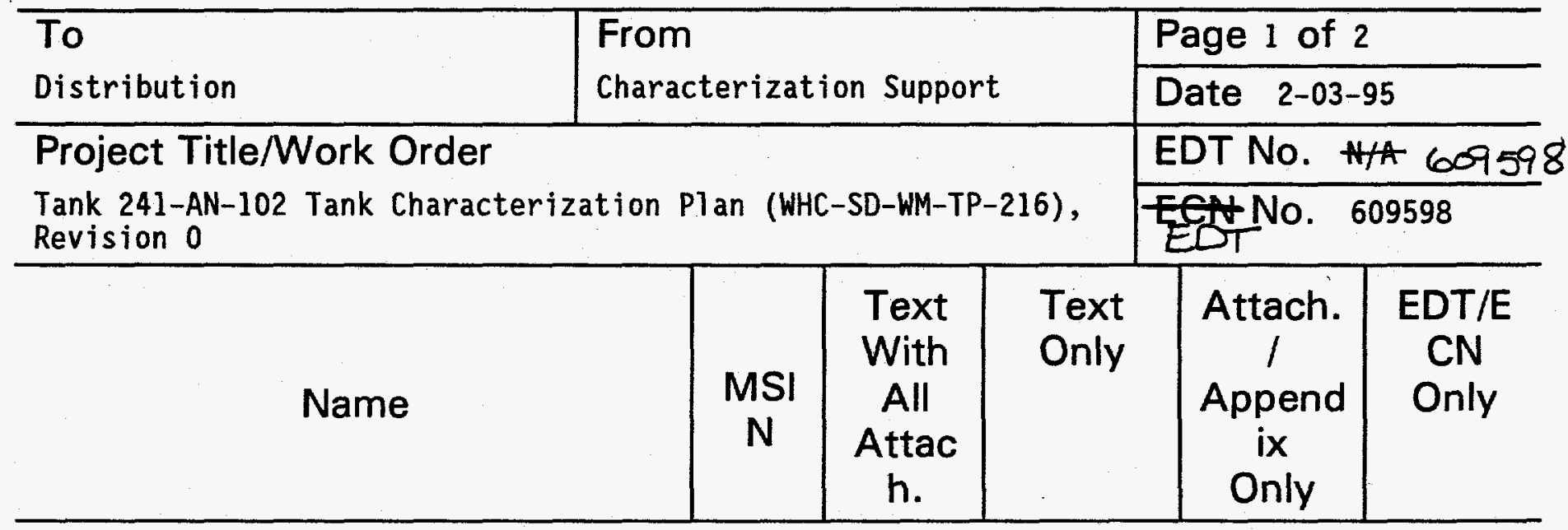

ONSITE

U. S. Department of Energy -

Richland Field office

C. A. Babe 1

S7-54

J. M. Clark

S7-54

$x$

MACTEC

J. P. Haney

D. R. Lincoln

S7-73

S7-73

J. A. Sheriff

$\mathrm{B} 1-42$

$x$
$x$
$x$

Pacific Northwest Laboratories

S. F. Bobrowski

K7-28

$x$

Westinghouse Hanford Company

R. Akita

K. E. Bell

K. G. Carothers

K. K. Cutsforth

T. F. Dale

J. L. Deichman

S. J. Eberlein

R. K. Fuller

V. W. Hall

J. R. Jewett

J. M. Jones

W. J. Kennedy

J. G. Kristofzski

J. S. Lee

G. L. Miller

P. M. Morant

A. D. Olguin

A. D. Rice

P. Sathyanarayana (2)

R. D. Schreiber (3)

$\begin{array}{ll}\text { T6-20 } & X \\ \text { T6-06 } & X \\ \text { R1-51 } & X \\ \text { S1-57 } & X \\ \text { T6-20 } & X \\ \text { H4-19 } & X \\ \text { S7-31 } & X \\ \text { T6-31 } & X \\ \text { H4-19 } & X \\ \text { T6-09 } & X \\ \text { S5-13 } & X \\ \text { S7-03 } & X \\ \text { T6-06 } & X \\ \text { S7-03 } & X \\ \text { T6-06 } & X \\ \text { H4-19 } & X \\ \text { S7-04 } & X \\ \text { T6-06 } & X \\ \text { R2-12 } & X \\ \text { R2-12 } & X\end{array}$



W. M. Smithers
C. L. Thomas.
T. C. Trible
M. D. Webb
Central Files

T7-25

H4-19

S1-57

$\mathrm{H} 4-25$

L8-04

L8-07

\section{OFFSITE}

U. S. Department of Energy - Headquarters

Office of Environmental Restoration and

Waste Management EM-563

12800 Middlebrook Road

Germantown, MD 20874

K. T. Lang

J. A. Poppiti

Los Alamos Technical Associates

750 Swift, Suite 14

Richland, WA 99352
A. T. Dicenso
C. J. Lindquist
T. T. Tran
G. P. Westleigh 


\section{DISCLAIMER}

Portions of this document may be illegible in electronic image products. Images are produced from the best available original document. 


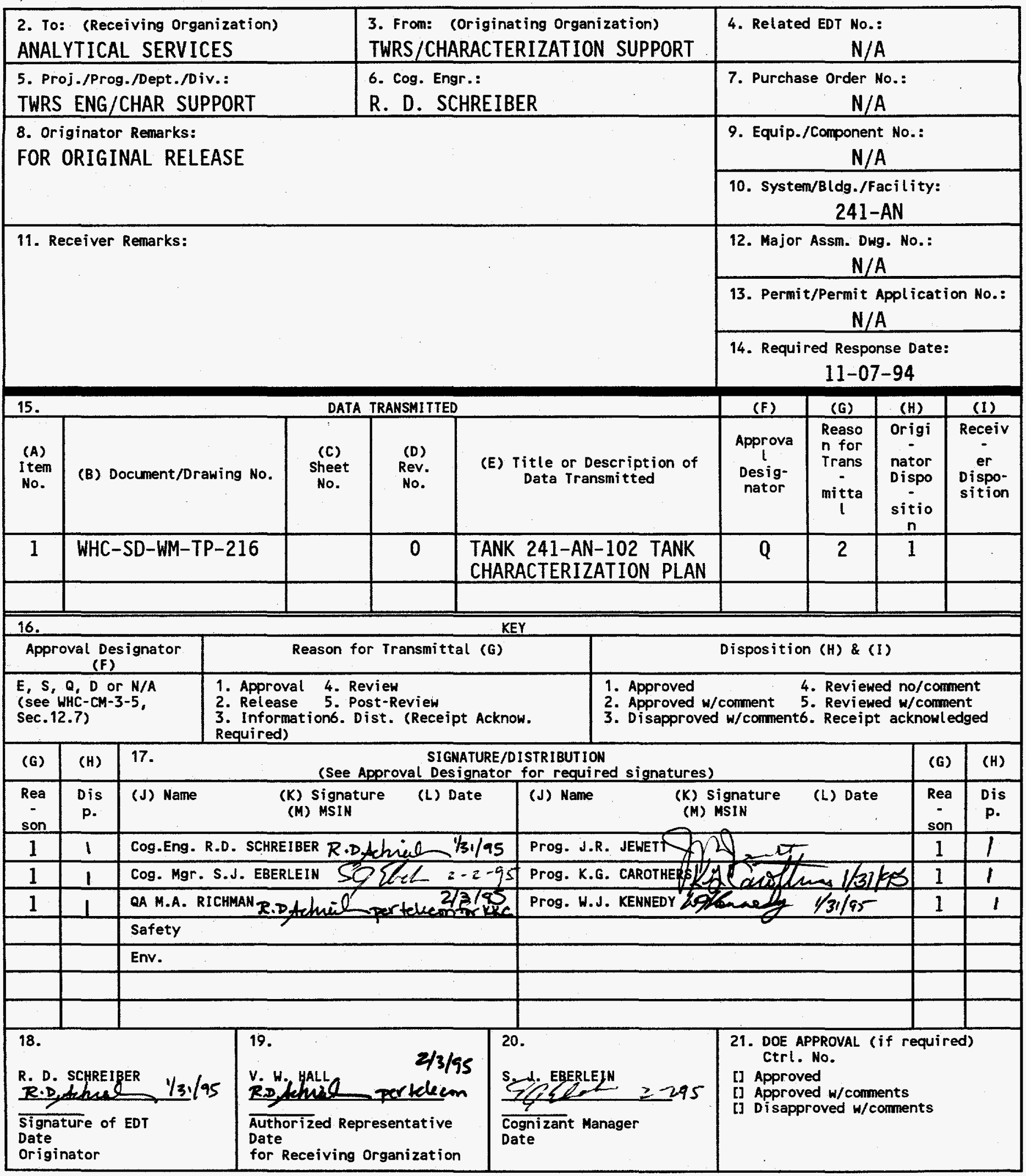

BD-7400-172-2 (04/94) GEF097

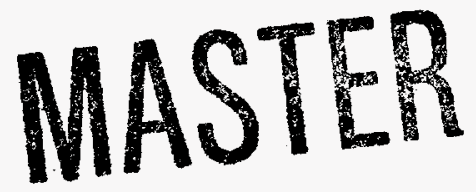




\section{RELEASE AUTHORIZATION}

Document Number:

WHC-SD-WM-TP-216, REV 0

Document Title: $\quad$ TANK 241-AN-102 TANK CHARACTERIZATION PLAN

Release Date: $\quad 2 / 3 / 95$

\section{This document was reviewed following the procedures described in WHC-CM-3-4 and is:}

\section{APPROVED FOR PUBLIC RELEASE}

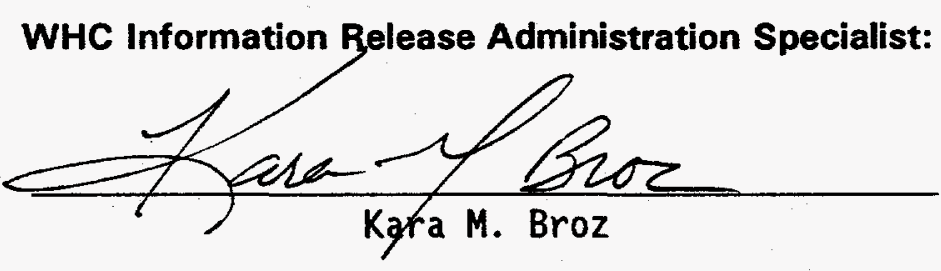

February 3, 1995

TRADEMARK DISCLAIMER. Reference herein to any specific commercial product, process, or service by trade name, trademark, manufacturer, or otherwise, does not necessarily const itute or imply its endorsement, recommendation, or favoring by the United States Government or any agency thereof or its contractors or subcontractors.

This report has been reproduced from the best available copy. Available in paper copy and microfiche. Printed in the United States of America. Available to the U.S. Department of Energy and its contractors from:

U.S. Department of Energy

Office of Scientific and Technical information (OSTI)

P.0. Box 62

Dak Ridge, TW 37831

Telephone: (615) 576-8401

Available to the public from:

U.S. Department of Commerce

National Technical Information Service (NTIS)

5285 Port Royal Road

Springfield, VA 22161

Telephone: (703) $487-4650$ 


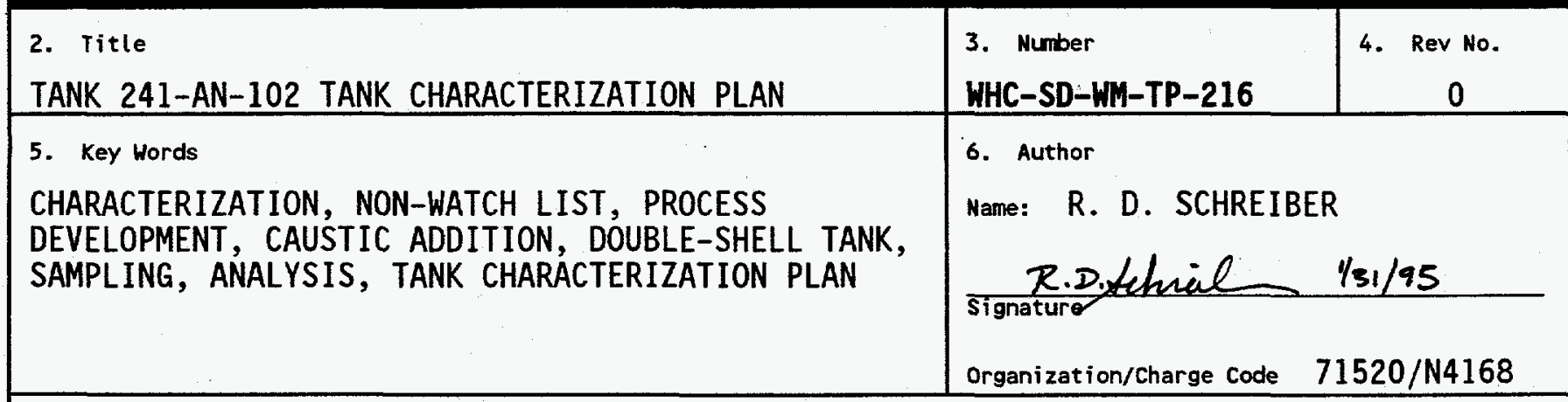

\section{Abstract}

This document is a plan which serves as the contractual agreement between the Characterization Program, Sampling Operations, PNL 325 Analytical Chemistry Laboratory, and WHC 222-S Laboratory. The scope of this plan is to provide guidance for the sampling and analysis of samples for tank 24l-AN-102. 
WHC-SD-WM-TP-216

Revision 0

1

\title{
Tank 241-AN-102 Tank Characterization Plan
}

\author{
Prepared for the U.S. Department of Energy \\ Office of Environmental Restoration \\ and Waste Management
}

\section{DISCLAIMER}

This report was prepared as an account of work sponsored by an agency of the United States Government. Neither the United States Government nor any agency thereof, nor any of their employees, makes any warranty, express or implied, or assumes any legal liability or responsibility for the accuracy, completeness, or usefulness of any information, apparatus, product, or process disclosed, or represents that its use would not infringe privately owned rights. Reference herein to any specific commercial product, process, or service by trade name, trademark, manufacturer, or otherwise does not necessarily constitute or imply its endorsement, recommendation, or favoring by the United States Government or any agency thereof. The views and opinions of authors expressed herein do not necessarily state or reflect those of the United States Government or any agency thereof. 
WHC-SD-WM-TP-216, REV. 0

CONTENTS

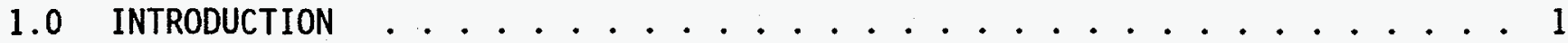

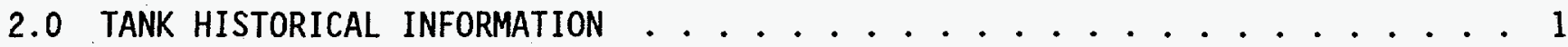

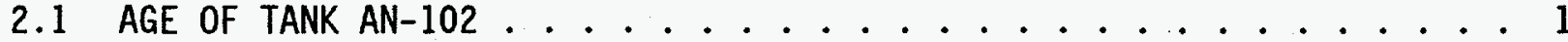

2.2 EXPECTED TANK CONTENTS ................... . . . . . .

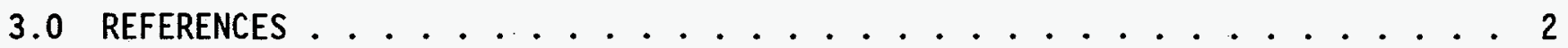
APPENDICES

A SAMPLING EVENT A: GRAB SAMPLING IN FISCAL YEAR $1995 \ldots \ldots \ldots$. . . . A-i

\section{LIST OF TABLES}

11994 Analysis Results for Tank AN-102 Supernate . . . . . . . . . . . 2

\section{LIST OF ABBREVIATIONS}

AN-102

CC

DQO

DST

OSD

QA

SST

TWRS

WHC tank 241-AN-102

complexant concentrate waste

data quality objective

double-shell tank

operational safety design

quality assurance

single-shell tank

Tank Waste Remediation System

Westinghouse Hanford Company 


\subsection{INTRODUCTION}

The Defense Nuclear Facilities Safety Board has advised the DOE to concentrate the near-term sampling and analysis activities on identification and resolution of safety issues (Conway 1993). The data quality objective (DQ0) process was chosen as a tool to be used to identify the sampling analytical needs for the resolution of safety issues. As a result, a revision in the Federal Facility Agreement and Consent Order (Tri-Party Agreement) milestone M-44-00 has been made, which states that "A Tank Characterization Plan (TCP) will also be developed for each double shell tank (DST) and single-shell tank (SST) using the DQO process . . Development of TCPs by the DQO process is intended to allow users (e.g., Hanford Facility user groups, regulators) to ensure their needs will be met and that resources are devoted to gaining only necessary information." This document satisfies that requirement for the tank 241-AN-102 (AN-102) fiscal year 1995 sampling activity.

\subsection{TANK HISTORICAL INFORMATION}

This section gives a summary of information describing tank AN-102. Included in the discussion will be the age of the tank, expected tank contents, and the riser which will be used for sampling. The number of samples to be taken for tank AN-102 will also be discussed.

\subsection{AGE OF TANK AN-102}

Tank AN-102 was constructed between 1980 and 1981 , and has a capacity of 1.14 Mgals (4.32 ML). Tank AN-102 has been used to store complexant concentrate (CC) waste.

\subsection{EXPECTED TANK CONTENTS}

Tank AN-102 contains complexant concentrate waste (CC) generated during evaporator operations to concentrate dilute waste and recover tank space. Complexant concentrate wastes contain a high concentration of organic complexants primarily as a result of past B-Plant operation to remove strontium from high-level waste (HLW) sludge. The presence of complexants presents several waste disposal problems, including chemical complexes with TRU elements, radionuclides migration in soils, waste concentration, and radionuclides removal compatibility with waste storage via vitrification.

Samples of the supernate from tank AN-102 were analyzed in 1994. The three tank samples were said to be indistinguishable from one another, indicating that the liquid in the tank is homogeneous. The results for the three samples were averaged, and this average result is given in Table 1 . 
WHC-SD-WM-TP-216, REV. 0

Table 1. 1994 Analys is Results for Tank AN-102 Supernate (Herting 1994)

\begin{tabular}{|c|c|c|}
\hline Analyte & Units & Average \\
\hline $\mathrm{OH}^{-}$ & $M$ & 0.24 \\
\hline TOC & $g / L$ & 26.3 \\
\hline $\operatorname{TIC}\left(\mathrm{CO}_{3}{ }^{2-}\right)$ & $M$ & 1.12 \\
\hline $\mathrm{Na}$ & $M$ & 11.2 \\
\hline $\mathrm{A} 7$ & $M$ & 0.55 \\
\hline $\mathrm{Ni}$ & $M$ & 0.006 \\
\hline $\mathrm{Ca}$ & $M$ & 0.011 \\
\hline $\mathrm{Cr}$ & $M$ & 0.0055 \\
\hline $\mathrm{P}$ & $M$ & 0.052 \\
\hline$S$ & $M$ & 0.15 \\
\hline $\mathrm{K}$ & $M$ & 0.10 \\
\hline$F^{-(1)}$ & $M$ & 0.11 \\
\hline $\mathrm{Cl}^{-}$ & $M$ & 0.11 \\
\hline $\mathrm{NO}_{2}^{-}$ & $M$ & 1.82 \\
\hline $\mathrm{NO}_{3}^{-}$ & $M$ & 3.57 \\
\hline $\mathrm{PO}_{4}^{3-}$ & $M$ & 0.052 \\
\hline $\mathrm{SO}_{4}{ }^{2-}$ & $M$ & 0.15 \\
\hline Density & $\mathrm{g} / \mathrm{mL}$ & 1.401 \\
\hline $\mathrm{pH}$ & -- & 13.09 \\
\hline$\% \mathrm{H}_{2} \mathrm{O}$ & $w t \%$ & 50.0 \\
\hline Total Alpha & $\mu \mathrm{Ci} / \mathrm{L}$ & 166 \\
\hline${ }^{137} \mathrm{Cs}$ & $\mu \mathrm{Ci} / \mathrm{L}$ & 382,000 \\
\hline${ }^{90} \mathrm{Sr}$ & $\mu \mathrm{Ci} / \mathrm{L}$ & 73,700 \\
\hline Mass Balance & $w t \%$ & 100.9 \\
\hline Charge $\mathrm{Ba}$ lance & Cation/Anion & 1.11 \\
\hline
\end{tabular}

(1) Fluoride value may be inaccurate due to interference from organic anions.

\subsection{REFERENCES}

Herting, D. L., Internal Memo to J. M. Jones, "Characterization of Supernate Samples from Tank 201-AN", 8E110-PCL94-112, dated December 28, 1994. 
WHC-SD-WM-TP-216, REV. 0

APPENDIX A

SAMPLING EVENT A: GRAB SAMPLING IN FISCAL YEAR 1995

1)

$A-i$ 
WHC-SD-WM-TP-216, REV. 0

CONTENTS

SAMPLING EVENT A: GRAB SAMPLING IN FISCAL YEAR 1995

A1.0 SPECIFIC TANK OBJECTIVE . . . . . . . . . . . . . . . . . . . A-1

A1.1 RELEVANT SAFETY ISSUES . . . . . . . . . . . . . . . . . . . . A-1

A1.1.1 AN-102 Characterization 0bjectives . . . . . . . . . . . A-1

A1.1.2 Applicable Data Quality Objectives . . . . . . . . . . . A-1

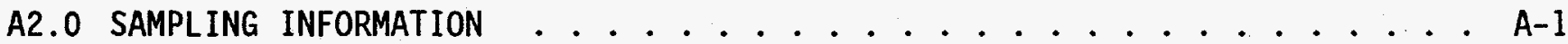

A2.1 SAMPLE COLLECTION .................... . A-2

A2.2 SAMPLE CUSTODY . . . . . . . . . . . . . . . . . . A-3

A3.0 LABORATORY INSTRUCTIONS . . . . . . . . . . . . . . . . . . . A-3

A3.1 TEST PLAN GUIDANCE . . . . . . . . . . . . . . . . . A-3

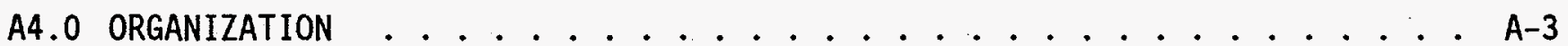

A5.0 ATTACHMENTS . . . . . . . . . . . . . . . . . . . . A-4

A6.0 REFERENCES . . . . . . . . . . . . . . . . . . . . . . A-4

\section{LIST OF TABLES}

A-1 Sampling Information for Tank AN-102 . . . . . . . . . . . . . A-2

A-2 Tank AN-102 Project Key Personnel List . . . . . . . . . . . . . . . A-4

\section{LIST OF ABBREVIATIONS}

AN-102 tank 241-AN-102

$\mathrm{CC}$

DQO

DST

OSD

QA

SST

TWRS

complexant concentrate waste

data quality objective

double-shell tank

operational safety design

quality assurance

single-shell tank

WHC

Tank Waste Remediation System

Westinghouse Hanford Company 


\section{A1.0 SPECIFIC TANK OBJECTIVES}

Tank 241-AN-102 is to be sampled for process development purposes. Since process development data needs are rarely ever defined such that they can be incorporated into a Data Quality Objectives effort, a test plan has been written to administer analytical guidance to the 222-S Laboratory for this sampling event. This Sampling and Analysis Plan will reference that test plan, and is focused on providing guidance to Sampling Operations personnel.

\section{A1.1 RELEVANT SAFETY ISSUES}

Tank 241-AN-102 is currently a non-Watch List tank which is used to store complexed waste. It has been found that the free hydroxide concentration for this tank is too low, causing the tank to be out of its Operational Specification Document (OSD) Timit.

\section{A1.1.1 AN-102 Characterization Objectives}

This sampling effort of tank $A N-102$ is focused on the relevant safety issue above. In order to rectify this issue, caustic must be added to tank AN-102. However, it is undetermined as of yet what effects the addition of caustic (hydroxide) would have on the waste present in the tank. Therefore, experiments will be performed to determine the effects of adding hydroxide to the tank (Herting 1995).

\section{A1.1.2 Applicable Data Quality Objectives}

Currently, there are no applicable Data Quality Objectives (DQOS) for this specific sampling event. Since this sampling event is for process development purposes only, the safety screening $\mathrm{DQO}$ has not been incorporated into this Sampling and Analys is Plan. Further, tank $A N-102$ is a non-Watch List tank, meaning that there are no safety-based DQOS applicable to this tank.

\section{A2.0 SAMPLING INFORMATION}

Tank AN-102 is to be sampled by the grab method. Two supernate samples and one sludge sample are to be taken from riser $21 A$. Table A-1 summarizes the necessary sampling information. 
WHC-SD-WM-TP-216, REV. 0

Table A-1: Sampling Information for Tank AN-102 ${ }^{\dagger}$.

\begin{tabular}{|c|c|c|c|c|}
\hline $\begin{array}{c}\text { Sample } \\
\text { Number }\end{array}$ & Sample Type & $\begin{array}{c}\text { Riser } \\
\text { Number }\end{array}$ & $\begin{array}{c}\text { String } \\
\text { Length } \\
\text { (inches) }\end{array}$ & $\begin{array}{c}\text { Sample } \\
\text { Elevation } \\
\text { (inches) }\end{array}$ \\
\hline 2 AN-95-1 & Supernate & $21 \mathrm{~A}$ & 388 & 225 \\
\hline $2 \mathrm{AN}-95-2$ & Supernate & $21 \mathrm{~A}$ & 576 & 37 \\
\hline $2 \mathrm{AN}-95-3$ & Sludge & 21A & 603 & 10 \\
\hline
\end{tabular}

\# (Jones 1995).
String (ength is measured from the top of the riser
to the mouth of the sample bottle.
Sample elevation is measured from the tank bottom to the
top of the sample bottle.

\section{A2.1 SAMPLE COLLECTION}

Grab samples are to be taken and shipped to the 222-S Laboratory by Sampling Operations in accordance with the Work Package 2E-94-01285. That work package shal1 also initiate the chain-of-custody for the samples. Approved plant operating procedures for the performance of liquid grab sampling are currently being developed. The work package for the AN-102 sampling event is being used in that development process. The following procedures will also be used for the AN-102 liquid grab sampling event:

- T0-100-052, "Segregate, Package, and Inventory Radioactive Waste"

- WHC-CM-2-14, "Responsibilities and Procedures for all Hazardous Material Shipments"

- WHC-SD-TP-SARP-001, "Sample Pig Transport System Safety Analysis Report for Packaging [onsite]"

- WHC-SD-WM-HSP-002, "Tank Farm Health and Safety P1an"

Samples shall be identified by a unique number before being shipped to the 222-S 1aboratory (Table A-1). The sampling team is responsible for documenting any problems and procedural changes affecting the validity of the sample in a field notebook. Sampling Operations shall enter this information in the comment section of the chain-of-custody form for addition to the data reports.

For this sampling event, no field blank shall be taken. The AN-102 samples to be taken during this activity are not for any RCRA regulatory purposes. Therefore, no field blank is necessary.

Sampling Operations shall send the samples to the 222-S Laboratory within 72 hours of removing the sample from tank AN-102. Sampling Operations is responsible for verbally not ifying the shift manager at the 1aboratory (373-2435) at least 24 hours in advance of an expected shipment. If samples are going to be delivered 
WHC-SD-WM-TP-216, REV. 0

after 3:00 pm, the laboratory shall be notified at least four hours in advance of actual sample shipment so that proper shift operations can be planned.

\section{A2.2 SAMPLE CUSTODY}

The chain-of-custody form is initiated by the sampling team as described in the work plan. Grab samples are shipped in a cask and sealed with a Waste Tank Sample Seal. All sample shipments are to be labeled with the following information:

WASTE TANK SAMPLE SEAL

Supervisor

Date of Sampling

Shipment No.
Sample No.

Time of Sampling

Serial No.

The sealed and labeled samples are shipped to the laboratory along with the chain-of-custody form, which identifies the tank and riser information. The receipt and control of samples in the Westinghouse Hanford 222-S Laboratory is described in L0-090-101. In the event that the $325 \mathrm{ACL}$ must receive samples, the guidance for receipt and control of samples in the $325 \mathrm{ACL}$ is described in PNL-ALO-051.

\section{A3.0 LABORATORY INSTRUCTIONS}

\section{A3.1 TEST PLAN GUIDANCE}

Analytical guidance for this process development effort will be administered through "Test Plan for Tank 102-AN Sample Testing" (Herting 1995), which explains the testing to be performed to determine the effect of adding caustic to the tank. This test plan explains in detail the experiments to be run on the waste from tank AN-102, and includes information regarding test objectives, requirements, and quality assurance.

\section{A4.0 ORGANIZATION}

The organization and responsibility of key personnel involved in this tank AN-102 characterization project are 1 isted in Table A-2. 
WHC-SD-WM-TP-216, REV. 0

Table A-2: Tank AN-102 Project Key Personnel List.

\begin{tabular}{||c|c|c||}
\hline Individual & Organization & Responsibility \\
\hline J. R. Jewett & $\begin{array}{c}\text { Process Chemistry } \\
\text { Laboratories }\end{array}$ & $\begin{array}{c}\text { Manager of Process } \\
\text { Chemistry Laboratories }\end{array}$ \\
\hline R. D. Schreiber & $\begin{array}{c}\text { TWRS Characterization } \\
\text { Support }\end{array}$ & $\begin{array}{c}\text { AN-102 Tank } \\
\text { Characterization Plan } \\
\text { Cognizant Engineer }\end{array}$ \\
\hline K. G. Carothers & $\begin{array}{c}\text { Waste Tank Plant } \\
\text { Engineering }\end{array}$ & Customer \\
\hline
\end{tabular}

\section{A5.0 ATTACHMENT}

Attached is the test plan to be used during this analysis activity.

\section{A6.0 REFERENCES}

Herting, D. L, Internal Memo to K. G. Carothers, "Test Plan for Tank 102-AN Sample Testing", 8E110-PCL95-007, dated January 19, 1995.

Jones, J. M., 1995, "Tank 241-AN-102 Sampling Information". 
From: $\quad$ Process Chemistry Laboratories

Phone: $\quad 373-2532$ T6-09

Date: January 19,1995

Subject: TEST PLAN FOR TANK 102-AN SAMPLE TESTING

To:

K. G. Carothers R1-51

$\begin{array}{ll}\text { cc: T. M. Blaak } & \text { Rl-67 } \\ \text { D. R. Bratzel } & 57-31 \\ \text { J. R. Jewett } & T 6-09 \\ \text { J. M. Jones } & 55-13 \\ \text { J. G. Kristofzski } & T 6-06 \\ \text { R. D. Schreiber } & \text { R2-12 } \\ \text { DLH File/LB } & \end{array}$

References: (1) Internal Memo, D. L. Herting to J. M. Jones, "Characterization of Supernate Samples from Tank 102-AN," dated December 28, 1994.

(2) Internal Memo, D. L. Herting to K. G. Carothers, "Characterization of Sludge Samples from Tank 241-AN-107," dated August 10, 1994.

Internal Memo, D. L. Herting to K. G. Carothers, "Results of Caustic Demand Tests on Tank 107-AN S7udge," dated November 30, 1994.

This internal memo constitutes a test plan (internal memo format) for the characterization and testing that our organization will perform on bottle-on-a-string samples to be taken from tank 102-AN. Your concurrence is required before laboratory work will commence. Please indicate your concurrence by signing in the space provided at the end of this memo.

The purpose of the characterization and testing is to support engineering planning activities for caustic mitigation. Support will be provided by analyzing the current chemistry of the tank sludge and supernate, and by measuring the caustic demand (amount of caustic needed to bring the waste up to $0.5 \mathrm{M}$ excess free hydroxide concentration) of the sludge and supernate. Characterization of three supernate samples was performed earlier, and is reported in Reference 1 .

\section{Sludge Characterization}

One sludge sample is available from the October 24,1994 , sampling of the tank. It was taken from riser 1B. A second sample will be taken in the near future, this one from riser 21A. Each sample will be analyzed independentiy. 
K. G. Carothers

Page 2

January 19, 1995

Solid and liquid fractions of the sludge samples will be analyzed separately, and reported in the same format that was used for the similar samples from tank 107-AN (Reference 2).

For each sludge sample, a $15 \mathrm{~mL}$ aliquot will be centrifuged. The liquid phase will be analyzed for the following:

$\mathrm{OH}^{-}$(free hydroxide)

IC (ion chromatography for $\mathrm{NO}_{3}^{-}, \mathrm{NO}_{2}^{-}, \mathrm{PO}_{4}^{3-}, \mathrm{SO}_{4}{ }^{2-}, \mathrm{Cl}^{-}, \mathrm{F}^{-}$)

ICP (inductively couple plasma spectroscopy for metals, including as a minimum, $\mathrm{Fe}, \mathrm{Al}, \mathrm{Mg}, \mathrm{Na}, \mathrm{Cr}, \mathrm{Mn}, \mathrm{Ca}, \mathrm{K}, \mathrm{Ni}$ )

TIC (total inorganic carbon -- $\mathrm{CO}_{3}{ }^{\mathrm{Z}^{-}}$)

TOC (total organic carbon)

$\mathrm{pH}$

$\mathrm{SPG}$

$\% \mathrm{H}_{2} \mathrm{O}$

GEA (gamma energy analysis)

Total Alpha

Total Beta

${ }^{90} \mathrm{Sr}$

The weight of the solid phase will be recorded, then the solids will be contacted with water to dissolve the water-soluble fraction of solids, as well as to remove most of the interstitial liquid. That sample will be centrifuged, and the water wash solution will be analyzed for the same species as the initial liquid phase.

The weight of solids remaining after the water wash will be recorded, then samples of the solids will be subjected to acid digestion and $\% \mathrm{H}_{2} \mathrm{O}$ analysis. The following analyses will be done on the acid solution resulting from the digestion: ICP, GEA, total alpha, total beta, and ${ }^{90} \mathrm{Sr}$.

Analytical results from the three fractions (liquid phase, water wash, and acid-dissolved solids) will be combined to obtain a chemical analysis of solid and liquid phases of the original sludge sample, including the relative amounts of solid and liquid in the sludge.

Some analyses will also be done on uncentrifuged portions of the sludge samples. These will include bulk sludge density, thermal analys is (differential scanning calorimetry and thermogravimetric analysis, DSC/TGA), viscosity as a function of temperature, and polarized light microscopy to identify solids.

An evaluation will be made on the feasibility of doing particle size distribution and settling rate analyses. Previous samples from tank 102-AN have been dark in color, but not as opaque as samples from tank 107-AN. 
K. G. Carothers

8E110-PCL95-007

Page 3

January 19,1995

\section{Supernate Characterization}

Three supernate samples were taken from riser 1B of tank 102-AN on October 21, 1994. Two new supernate samples will be taken from riser $21 \mathrm{~A}$ in the near future. The two new samples will be characterized according to the same methods used for the earlier samples (Reference 1), except that DSC/TGA analysis will be added. The complete list of analytes for the supernate samples, then, is as follows:

$\begin{array}{llllll}\mathrm{OH}^{-} & \mathrm{IC} & \mathrm{ICP} & \text { TOC } & \text { TIC } & \text { Density } \\ \mathrm{pH} & \% \mathrm{H}_{2} \mathrm{O} & \text { AT } & { }^{137} \mathrm{CS} & { }^{90} \mathrm{Sr} & \text { DSC/TGA }\end{array}$

Caustic Demand

Caustic demand tests will be performed on two composite samples -- one for the former and future supernate samples, and one for the sludge samples. Analysis of samples for hydroxide concentration, using procedure number LA-211-102, will be used to determine the free hydroxide concentration in the solutions.

Sufficient caustic (standardized $19.4 \mathrm{M} \mathrm{NaOH}$ ) will be added to each of seven $5 \mathrm{~mL}$ aliquots of the supernate composite sample in order to achieve calculated free hydroxide concentrations of $0.4,0.55,0.7,0.85,1.0,2.0$, and $3.0 \mathrm{M}$ hydroxide. The actual concentrations will be less than calculated due to the buffering capacity of the waste. The samples will then be stirred for 24 hours at ambient temperature, then centrifuged. The weight of centrifuged solids will be recorded, and the liquid phase will be analyzed for hydroxide, aluminum, and carbonate.

The lower five hydroxide levels chosen will almost certainly encompass the targeted $0.5 \mathrm{M}$ excess hydroxide. The amount of caustic needed to reach 0.5 $M$ hydroxide, as-analyzed, will then be calculated by interpolation between the points measured. The two higher hydroxide levels will be used to determine whether the caustic addition might cause precipitation of carbonate, leading to a dramatic rise in viscosity.

The same experiment will be done using $5 \mathrm{~mL}$ aliquots of the sludge composite sample, in order to determine whether the presence of the solids in the sludge might react with the added hydroxide. For example, it is possible that aluminum hydroxide in the sludge could dissolve when caustic is added (Reference 3), forming sodium aluminate and consuming some of the added hydroxide. To account for the potential higher caustic demand of the sludge, the targeted concentrations will be changed to $0.5,0.75,1.0,1.25$, and $1.5 \mathrm{M}$ hydroxide. 
K. G. Carothers

Page 4

Januar-y 19,1995

\section{Qual ity Assurance}

Based on the requirements in "Management Requirements and Procedures," WHC-CM-1-3, MRP 5.43, this test plan is assigned Impact Level 4. Approval signatures are required (see end of this memo) from the author, immediate manager, and customer.

For every sample submitted for analysis, a duplicate sample will be submitted for the same analyses. This will be a "blind" duplicate, i.e., the analyst will not be aware of which samples are duplicates.

Analytical work will conform to "Analytical Chemistry Services Laboratories Quality Assurance Plan," WHC-SD-CP-QAPP-001. Samples will be analyzed in batches of from one to five samples per batch. With each batch will be run an instrument standard and a spike, blank, tracer, or methods standard.

All sample breakdown and treatment activities will be recorded in a bound and numbered laboratory notebook. Detailed written procedures will be recorded in the notebook and approved by the manager before work begins; observations and data will be recorded as the work is done.

Please call me on 373-2532 if you have any questions.

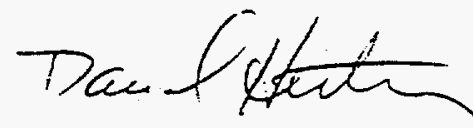

D. L. Herting, Senior Principal Scientist

Process Chemistry Laboratories

dis

CONCURRENCE:

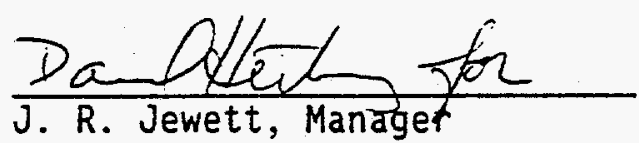

Process Chemistry Laboratories

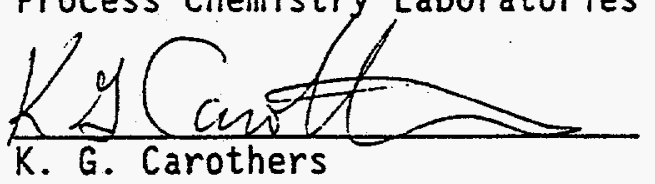

Waste Tank Plant Engineering

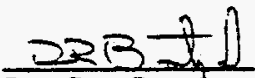

D. R. Bratze]

Analytical Integration 